\title{
SEDIMENT- AND MORPHODYNAMICS OF SHOREFACE NOURISHMENTS ALONG THE NORTH-HOLLAND COAST
}

\author{
Ben de Sonneville ${ }^{1}$ and Ad van der Spek ${ }^{1}$
}

\begin{abstract}
The Dutch coastal maintenance policy which was implemented in 1990 aims at fighting structural erosion by nourishing sand. Initially, the beaches were nourished. The lifetime of these beach nourishments turned out to be relatively short ( 2 yrs), especially at identified erosion 'hotspots' along the North-Holland coast (e.g. Egmond aan Zee). Therefore, from 1999 on, an alternative approach was considered, in which beach nourishments were combined with large nourishments on the shoreface (seaward of the outer breaker bar). In recent years, the evolution of individual shoreface nourishments was analyzed on a spatial scale of kilometres and a temporal scale of years, with a focus on their cross-shore development (e.g., Van Duin et al., 2004). In these studies, their alongshore interaction received little attention. The main objective of the present study is to investigate the evolution and lifetime of five large ( 1-2 million m3) shoreface nourishments applied between 1999 and 2005 on a spatial scale that includes the larger part of the North-Holland coast ( 40km). The analysis of bathymetrical data shows that all five shoreface nourishments evolved into new outer bars with deep troughs on their landward side, that temporarily interrupted the 'autonomous' cyclic offshore migration of breaker bars (e.g. Wijnberg, 1995). Alongshore, the nourishment placed at Camperduin in 2002 connected to the existing outer bar, while the nourishments placed at Egmond aan Zee and Bergen in 1999 and 2000 respectively, remained isolated. The 2004 Egmond and 2005 Bergen nourishments interconnected into a long bar. At Camperduin, the newly formed outer bar remained quite stable in the years after its placement. The bars resulting from the 1999 Egmond aan Zee and 2000 Bergen nourishments, however, almost fully disintegrated within five years, while the interconnected bar of the 2004 and 2005 nourishments is still largely intact after 5 years. The results suggest that the effectiveness of shoreface nourishments is influenced by their shore-parallel length and their ability to connect to surrounding (natural or nourishment) bars. The observed morphodynamic patterns suggest that the 'lost' sand is mainly redistributed to the breaker zone, and further transported alongshore.
\end{abstract}

Keywords: shoreface nourishments; coastal morphodynamics; data analysis; North-Holland; breaker bars

\section{INTRODUCTION}

The coastal policy in the Netherlands is primarily aimed at protecting the low-lying areas against flooding. Historically, the coastal area was (and is) protected by series of dune ridges. Vulnerable locations in the beach-dune system were reinforced by building groynes, dikes and seawalls. Since about 1950, sand nourishments were occasionally applied to reinforce weak parts of the sea defence. In 1990, the Dutch government decided to fight structural coastal erosion. A reference coastline was appointed that was based on the coastline position of that year. Since then, the actual coastline position is checked against this reference every year (see, e.g., Hillen \& Roelse, 1995; Van Koningsveld \& Mulder, 2004). Locations that have lost significant volumes of sediment due to coastal erosion are nourished with sand.

Initially, nourishments were placed on the beach. The lifetime of these beach nourishments turned out to be relatively short ( 2 yrs $)$, especially at particular erosion 'hotspots' along the North-Holland coast (e.g. Egmond aan Zee). Therefore, from 1999 on, an alternative approach was considered, in which beach nourishments were combined with large nourishments on the shoreface (directly seawards of the outer breaker bar). Compared to beach nourishments, these shoreface nourishments have the advantage of being more economic and easier to apply.

Since 1999, the behaviour of individual shoreface nourishments has been analyzed on a spatial scale of about 5-10 km and a temporal scale of years (e.g. Duin et al., 2004; Grunnet et al., 2005; Spanhoff \& Van der Graaff, 2007; Ojeda et al., 2008). The nourishments were found to reshape into a bar with a related trough on the landward side within a few months. This newly formed bar interrupted the autonomous bar behaviour, which was typically characterized by bar generation near the shoreline, followed by offshore migration and decay (Ruessink and Kroon, 1994; Wijnberg and Terwindt, 1995). In some cases, the bar resulting from the nourishment even caused the existing outer bar to migrate shoreward. During this period of interruption, the shoreface nourishments were hypothesized to contribute to restoring the beach profile through two effects (e.g., Van Duin et al.,

\footnotetext{
${ }^{1}$ Deltares, Rotterdamseweg 185, P.O. Box 177, 2600 MH Delft, The Netherlands
} 
2004; Grunnet et al., 2005), namely a feeder effect and a lee effect. The lee effect refers to the ability of the berm to increase wave dissipation with a corresponding local reduction of the wave-induced alongshore current, which leads to an increase in deposition of sediment from the alongshore sediment transport (Grunnet et al., 2005). The feeder effect comprises the onshore movement of nourished sand by wave asymmetry and slow onshore currents. These two effects are key assumptions in the present design of nourishments for coastal maintenance purposes. The period of interruption of the autonomous bar behaviour is frequently used as a measure for the lifetime of shoreface nourishments.

The lifetime of shoreface nourishments varies. Van Duin et al. (2004) concluded that the shoreface nourishment applied at Egmond aan Zee in 1999 disappeared within two years. Grunnet et al. (2005) showed that the NOURTEC shoreface nourishment applied at Terschelling in 1993 halted the autonomous offshore migration of the bars for a period of 6 to 7 years. At Noordwijk, a nourishment applied in 1998 was detectable by wave breaking patterns in Argus-images up to 8 years after the nourishment (Ruessink et al., 2012). To date, the factors controlling the lifetime of shoreface nourishments are not well understood. Ojeda et al. (2008) suggest that the long lifetime of the nourishment at Noordwijk could be influenced by the comparatively far offshore position of the nourishment, the large grain size of the nourished sand and the large size of the nourishment, relative to the size of the existing sandbars.

The main objective of the present study is to investigate and compare the evolution and lifetime of five large ( 1-2 million m3) shoreface nourishments, all applied at a $15 \mathrm{~km}$-long stretch of the NorthHolland coast between 1999 and 2005, in order to get a better understanding of the factors controlling their lifetime. Changes in nearshore bathymetry reflect the morphodynamic evolution of shoreface nourishments. For this purpose, bathymetrical data that were collected on a fixed grid since 1965 were analyzed. First the data for the period 1980 to 1995 was analyzed to obtain an understanding of the coastal development prior to the shoreface nourishments. Next, the period 1996 to 2010 was considered. The study area extended about $40 \mathrm{~km}$ (from IJmuiden to Callantsoog, see Fig. 1b) in order to obtain a good understanding of the interaction of the shoreface nourishments with adjacent coastal zones.

\section{SITE AND DATA DESCRIPTION}

The North-Holland coast is located centrally in the Dutch coast (see Figure 1a). It is a fairly uniform stretch of sandy coast, bounded by the harbour moles of IJmuiden in the south, and Marsdiep Inlet in the north (see Figure 1b). North of Camperduin lies the $6 \mathrm{~km}$ long Hondsbossche and Pettemer Seawall, which presently acts as a headland that slightly protrudes into the sea (Wijnberg, 2002). The median grain size of the sediment at the North-Holland coast ranges from about $150 \mu \mathrm{m}$ (beach) to $250 \mu \mathrm{m}$ ( $\sim 1 \mathrm{~km}$ offshore). Near Camperduin, patches of coarser sediments $(\sim 400 \mu \mathrm{m})$ are occasionally found. 

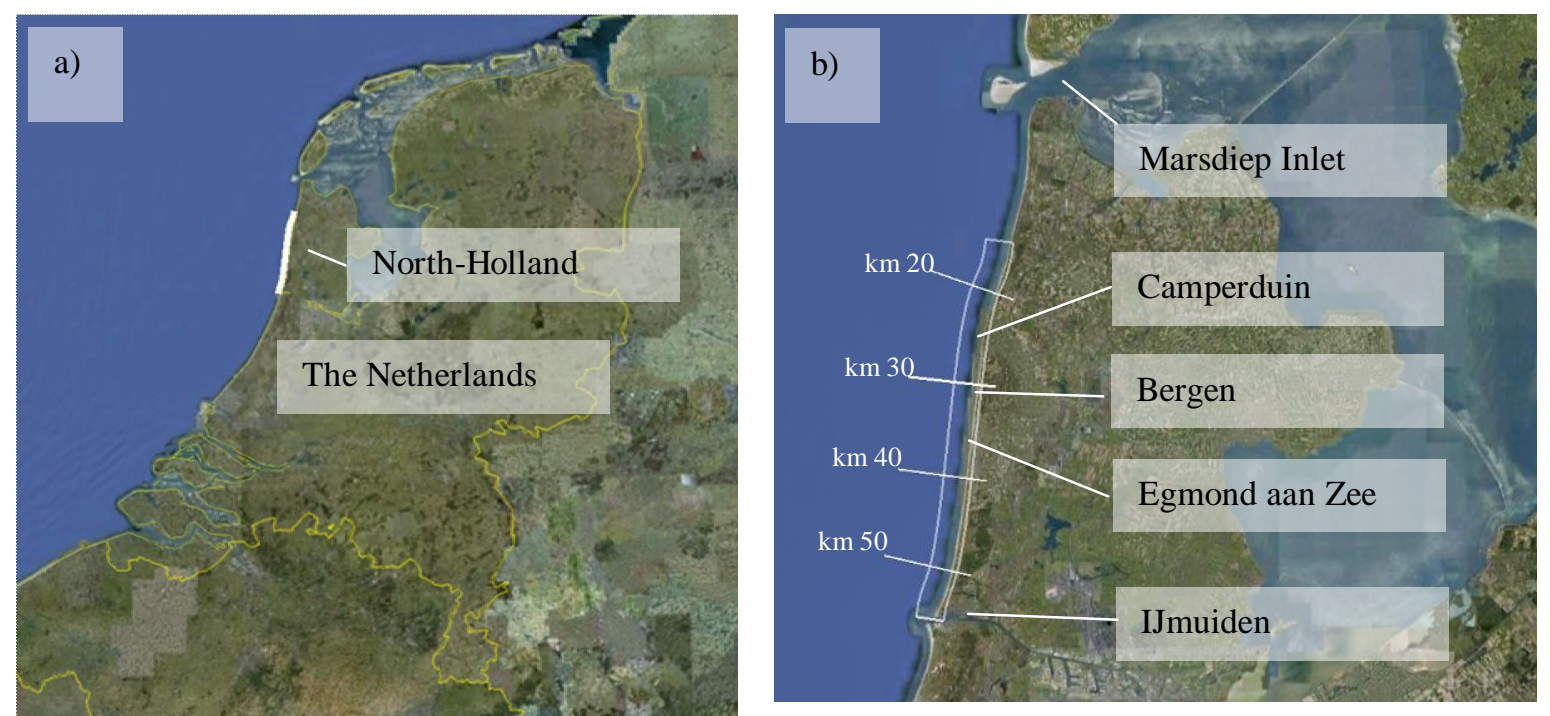

Figure 1: (a) an image of the Netherlands, with the study area indicated by a white patch (left). (b) zoom-in with selected coastal cities. Alongshore, relevant beach pole positions are also indicated.

The nearshore morphology of the North-Holland coast is characterized by three bars (a swash bar, an inner bar and an outer bar). The swash bar has a lifetime of several weeks to months (Quartel et al., 2007). The inner and outer bars are multi-annual features. A bar goes through a cycle with three phases (Shand et al., 1999): (phase I) bar generation near the intertidal zone, (phase II) net offshore migration through the surfzone, and (phase III) bar decay at a depth of 5-10m. The decay of the outer bar triggers the birth of a new bar (phase I) and the net offshore migration of the inner bar that now has become the new outer bar (phase II). At Egmond aan Zee, this cycle takes about 15 years. Occasionally, alongshore gradients in bar-migration rate may cause a sandbar to be in different phases alongshore. When a bar breaks up and attaches to a landward-located bar, this is referred to as bar switching (Shand et al., 1999).

The North-Holland coast was heavily nourished since 1990. Table 1 shows the nourishments applied at the North Holland coast from 1999 to 2009.

Table 1: overview of nourishments between IJmuiden and Camperduin from 1999 to 2009 (source: Rijkswaterstaat). The five large shoreface nourishments are indicated in blue.

\begin{tabular}{|l|l|l|c|l|}
\hline Site & RSP location & Year & Volume [million $\left.\mathbf{~ m}^{\mathbf{3}}\right]$ & Type \\
\hline Egmond & $\mathbf{3 7 - 3 9 k m}$ & $\mathbf{1 9 9 9}$ & 0.88 & shoreface nourishment \\
\hline Egmond & $37-39 \mathrm{~km}$ & 1999 & 0.21 & beach nourishment \\
\hline Bergen aan Zee & $32-34 \mathrm{~km}$ & 1999 & 0.21 & beach nourishment \\
\hline Egmond & $38-39 \mathrm{~km}$ & 2000 & 0.21 & beach nourishment \\
\hline Bergen aan Zee & $32-33 \mathrm{~km}$ & 2000 & 0.23 & beach nourishment \\
\hline Bergen aan Zee & $\mathbf{3 2 - 3 4 k m}$ & $\mathbf{2 0 0 0}$ & 0.99 & shoreface nourishment \\
\hline Bergen & $28-30 \mathrm{~km}$ & 2001 & 0.51 & beach nourishment \\
\hline Petten & $18-20 \mathrm{~km}$ & 2002 & 0.50 & beach nourishment \\
\hline Camperduin & $\mathbf{2 6 - 3 0 k m}$ & $\mathbf{2 0 0 2}$ & 1.97 & shoreface nourishment \\
\hline Petten & $19-21 \mathrm{~km}$ & 2003 & 0.23 & beach nourishment \\
\hline Camperduin & $25-26 \mathrm{~km}$ & 2003 & 0.36 & beach nourishment \\
\hline Egmond aan Zee & $\mathbf{3 6 - 4 0 k m}$ & $\mathbf{2 0 0 4}$ & 1.80 & shoreface nourishment \\
\hline Petten & $20-21 \mathrm{~km}$ & 2004 & 0.13 & beach nourishment \\
\hline Camperduin & $25-26 \mathrm{~km}$ & 2004 & 0.22 & beach nourishment \\
\hline Egmond & $37-39 \mathrm{~km}$ & 2005 & 0.49 & beach nourishment \\
\hline Castricum & $46-48 \mathrm{~km}$ & 2005 & 0.52 & beach nourishment \\
\hline Bergen & $\mathbf{3 1 - 3 6 k m}$ & $\mathbf{2 0 0 5}$ & 1.50 & shoreface nourishment \\
\hline Bergen & $32-34 \mathrm{~km}$ & 2005 & 0.30 & beach nourishment \\
\hline Pettemer Zeewering & $15-30 \mathrm{~km}$ & 2009 & 5.70 & shoreface nourishment \\
\hline
\end{tabular}


The present study focuses on the five large shoreface nourishments indicated in blue in Table 1 . All nourishments were placed in the active zone, against the outer bar, raising the seabed to a level of about NAP $-5 \mathrm{~m}$, about $1 \mathrm{~km}$ from the shoreline. The grain size of all five nourishments was comparable with the grain size of the original sediments $(200-250 \mu \mathrm{m})$.

The wave climate at North-Holland is governed by westerly storms. The offshore significant wave height with a yearly return period is in the order of $6 \mathrm{~m}$, with a peak wave period of about $10 \mathrm{~s}$. The yearly averaged offshore significant wave height is about $1 \mathrm{~m}$, with a corresponding peak wave period of $6 \mathrm{~s}$. The spatial variation of the offshore wave climate is small (Wijnberg, 2002). The mean tidal range at Egmond aan Zee is about $1.6 \mathrm{~m}$, leading to shore-parallel flood and ebb currents in the order of $0.4 \mathrm{~m} / \mathrm{s}$ (Wijnberg, 2002).

\section{METHODOLOGY}

The data analysis is based on JARKUS bathymetrical surveys from 1980 to 2010. These data were collected by the Dutch Department of Waterways and Public Works. The surveys typically cover the coastal zone from an offshore depth of about $15 \mathrm{~m}$ up to and including the first row of dunes (a crossshore distance of about $2-3 \mathrm{~km}$ ).

In order to improve the visualization of the bar development, the bathymetry of the North-Holland coast was de-curved, by interpolating the data to a curvilinear grid (see Figure 2a) following the reference beach poles $(\mathrm{RSP}=0 \mathrm{~m})$ at the coast. Then, the grid was plotted orthogonally (see Figure $2 \mathrm{~b}$ ) and stretched in cross-shore direction (see Figure 2c). Finally, for a three-dimensional view, the data is shown from birds-eye perspective. This method of visualization allows a view of $40 \mathrm{~km}$ of coastline in a single figure, with a clear view of the morphologic features (see Figure 2d).
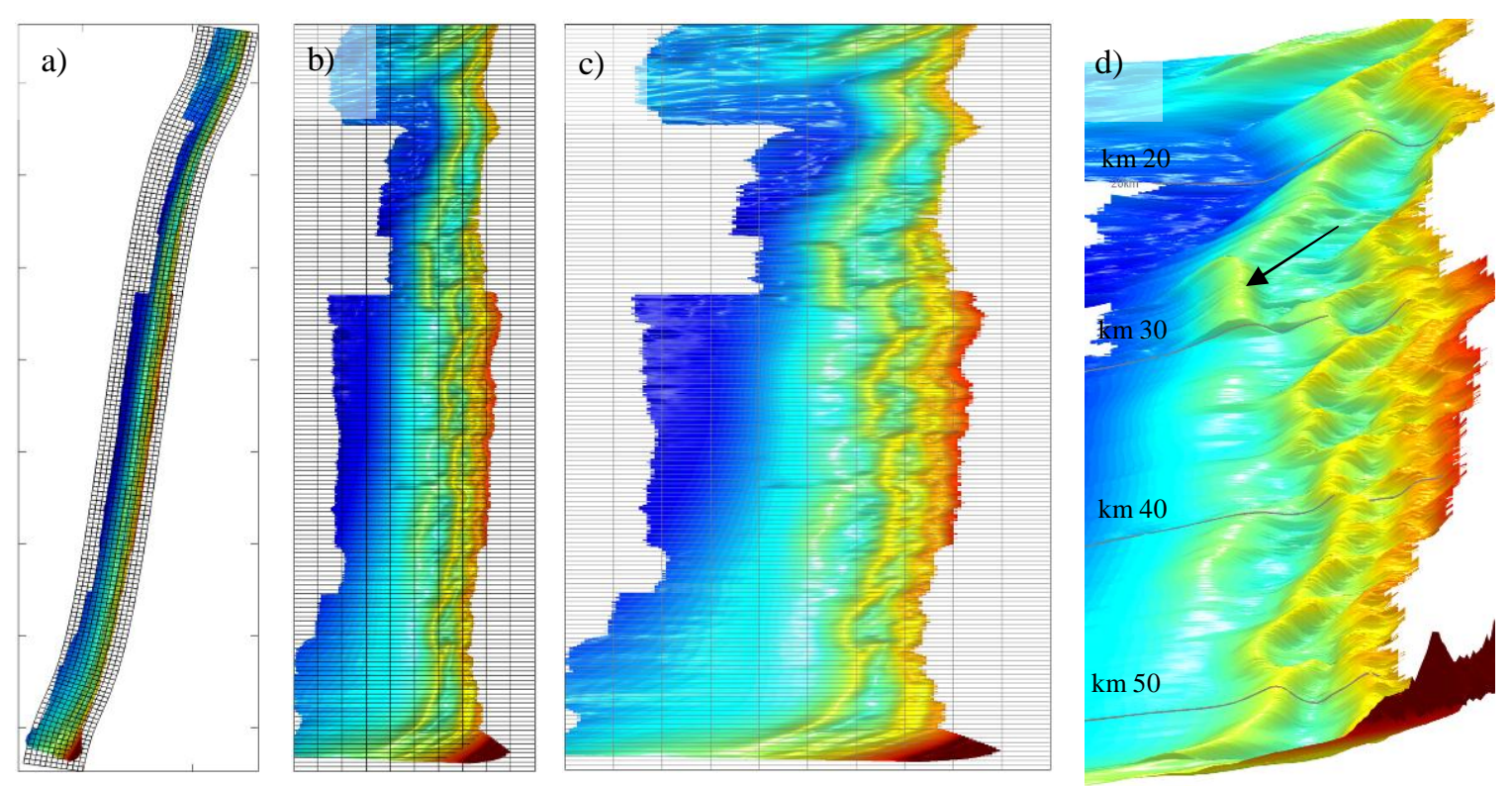

Figure 2: example of de-curving and stretching of the bathymetry. Figure 1d shows a three-dimensional image of $40 \mathrm{~km}$ of the North-Holland coast (year of 2003), including the shoreface nourishment applied at Camperduin in 2002 (indicated by a black arrow).

For an alongshore reference, the beach poles of $\mathrm{km} \mathrm{20,} \mathrm{km} \mathrm{30,} \mathrm{km} 40$ and $\mathrm{km} 50$ are shown in Figure 2d (NB this reference system is based on the alongshore distance relative to Den Helder in the north; Fig. 1b). Camperduin (at km 26) is located towards the north, within section $\mathrm{km} 20-\mathrm{km} 30$. Egmond aan Zee (km 38) and Bergen (km 33) are located in the middle section ( $\mathrm{km} 30-\mathrm{km} \mathrm{40).}$ 


\section{RESULTS}

(1) Data analysis of years $1980-1995$

Figure 3 shows the bathymetrical data of the period 1980 to 1995, the period before shoreface nourishments were applied.

a)

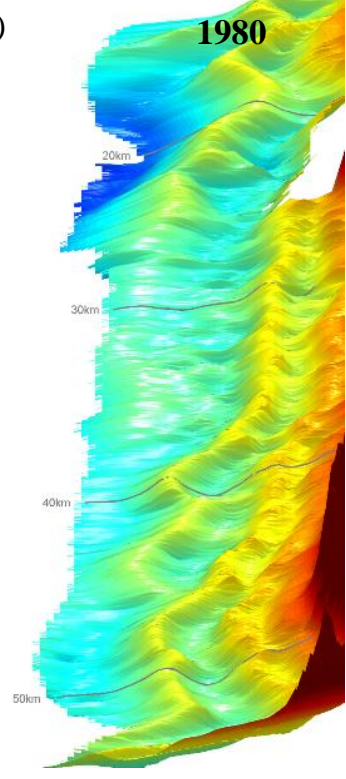

b)

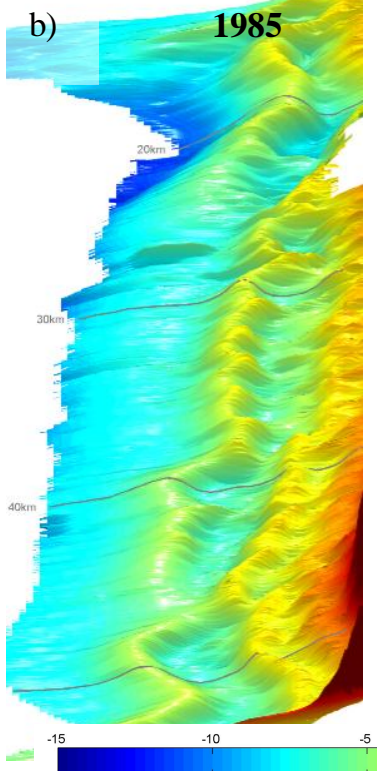

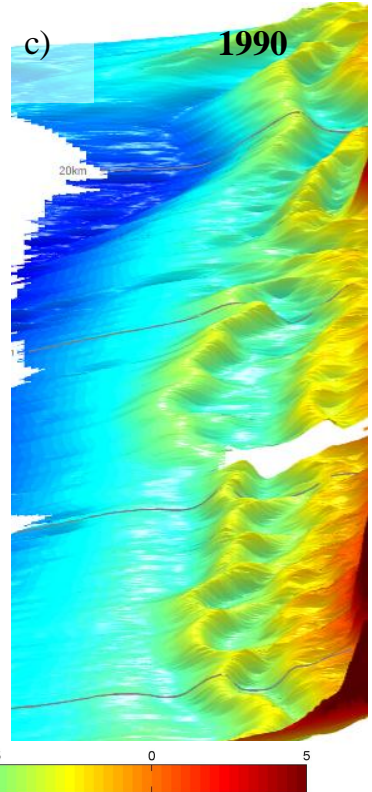

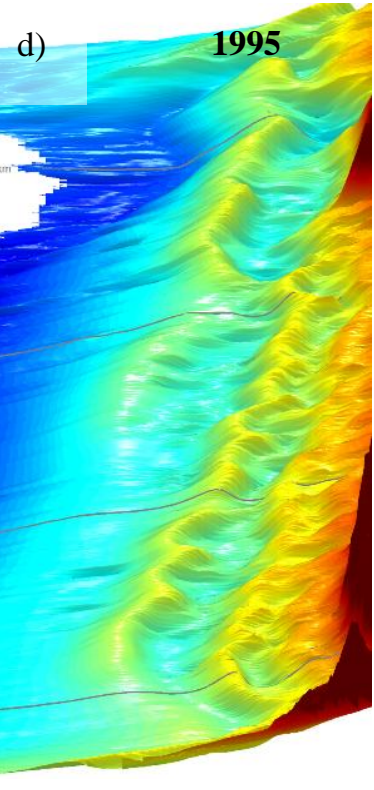

Figure 3: seabed bathymetry of 1980, 1985, 1990 and 1995, showing a full bar cycle before the period of the large shoreface nourishments. From north to south, beach poles $\mathrm{km} \mathrm{20,} \mathrm{km} \mathrm{30,} \mathrm{km} 40$ and $\mathrm{km} 50$ are indicated as alongshore reference.

The results confirm that the development of the shoreface is dominated by cyclic offshore bar migration. Along the coast, the offshore position of the outer bar varies. There appear to be three sections that are in a different phase. In 1980 (Figure 3a), the middle section (km $30-\mathrm{km} \mathrm{40)}$ is in phase I (bar generation), while the southern section ( $\mathrm{km} 40-\mathrm{km} \mathrm{50)}$ ), is well into phase II (offshore migration) and the northern section ( $\mathrm{km} 25-\mathrm{km} \mathrm{30}$ ) is in phase III (decay). By 1990, all sections appear to have shifted phase: the bar in the middle section has migrated offshore (phase II), while the bar in the south has decayed (phase III). In the north a new bar is about to develop (phase I). Towards 1995, the sections are in about similar phases as in 1980, which confirms that the migration rate of the individual alongshore sections is in the same order of magnitude, and the bar cycle is indeed about 15 years. Occasionally, bar switching is observed, e.g. in 1990, when the offshore migrated bar in the middle section connects to the just generated bar in the south. Alongshore bar migration is not observed.

Quite interestingly, cyclic offshore bar migration is not observed in the most northern section $(\sim 20 \mathrm{~km})$, in front of the Hondsbossche and Pettemer Seawall. The hard defence appears to induce a more or less stable morphology, consisting of a bar in combination with a steep seaward slope.

(2) Data analysis of years $1996-2010$

Figure 4 and 5 show the bathymetrical data of the period 1996 - 2010; the period in which the large shoreface nourishments were applied. 

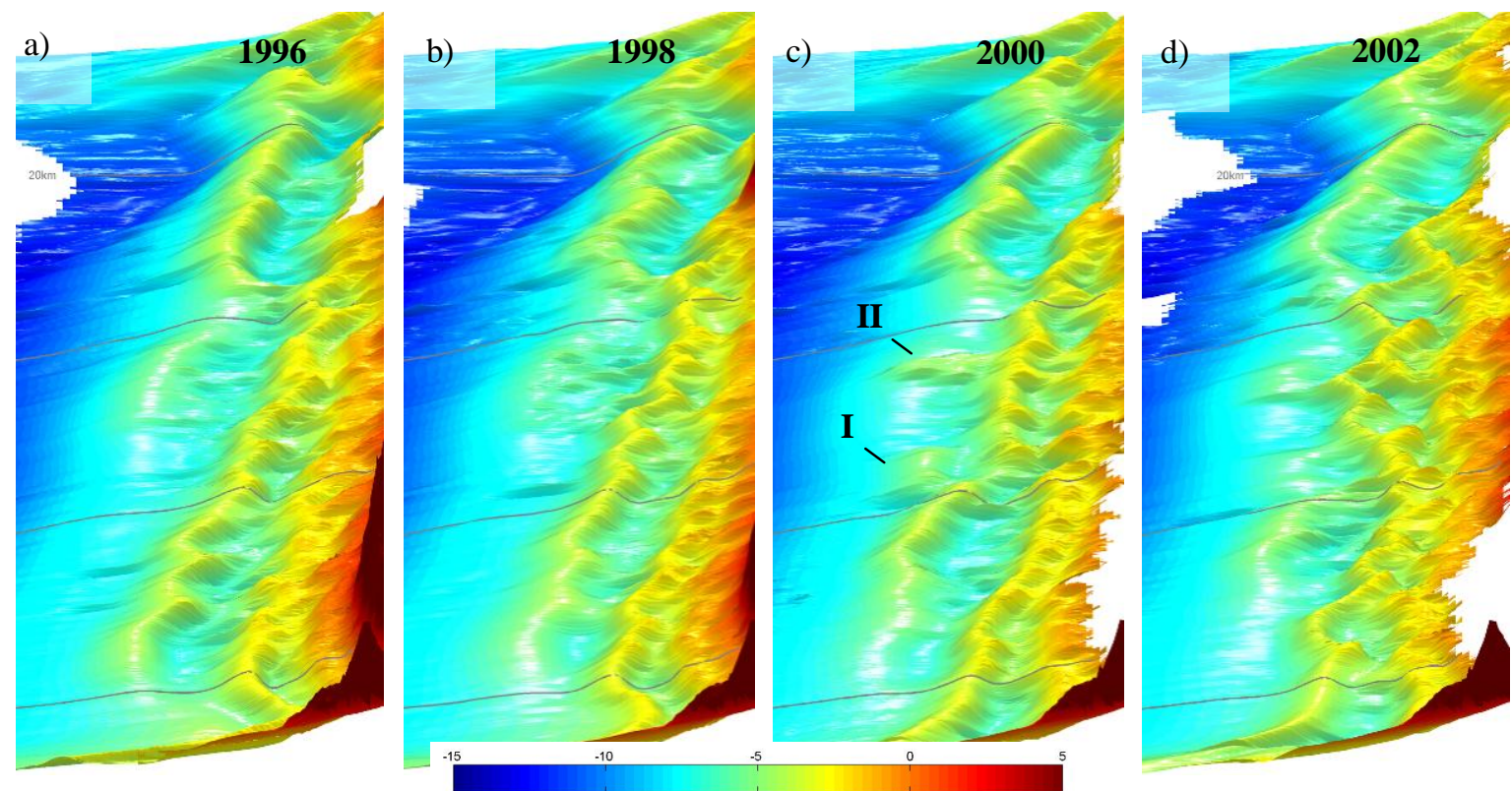

Figure 4: seabed bathymetry of 1996, 1998, 2000 and 2002, showing the bars resulting from the shoreface nourishments placed at Egmond aan Zee in 1999 (I) and Bergen in 2000 (II).
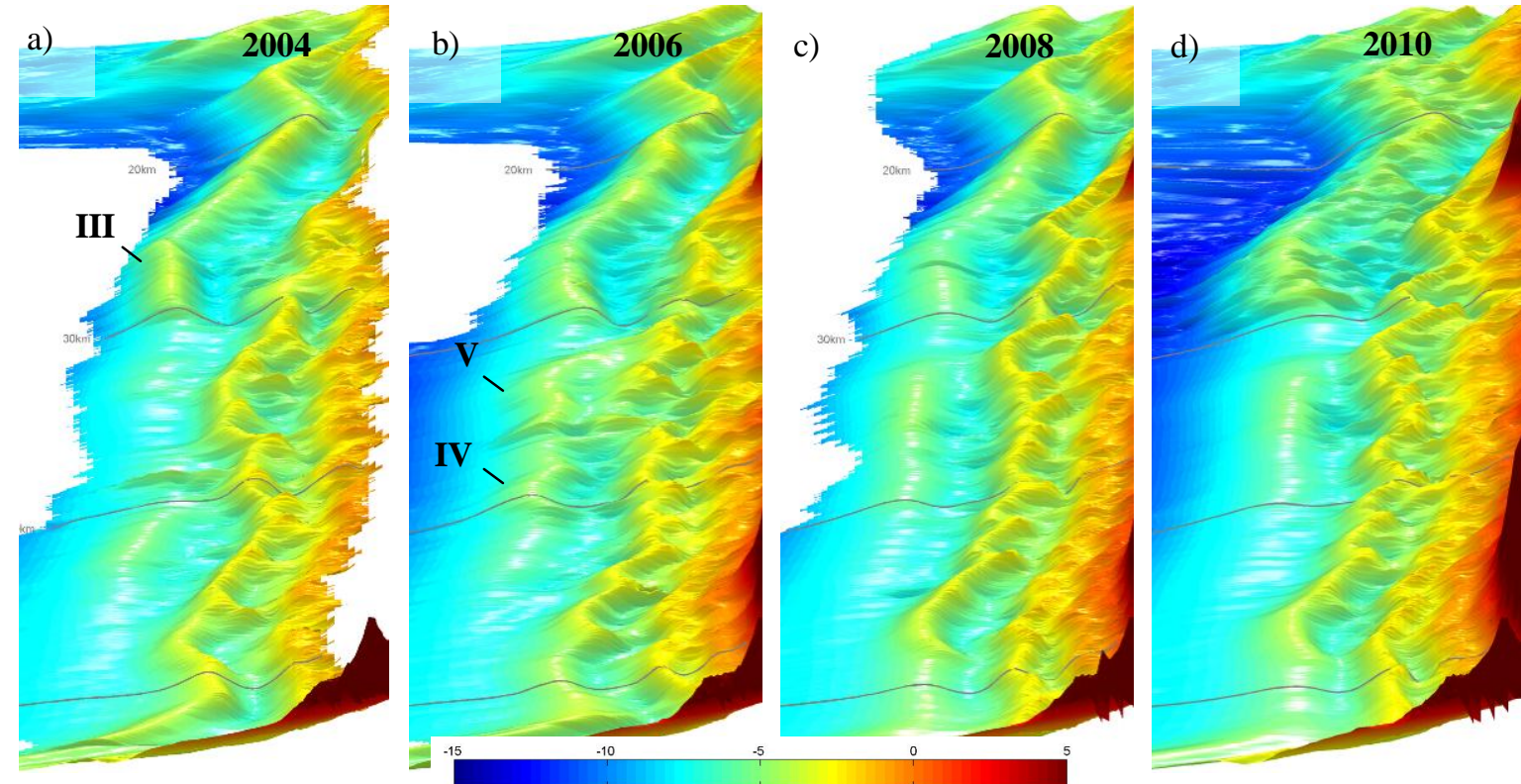

Figure 5: seabed bathymetry of 2004, 2006, 2008 and 2010, showing the bars resulting from the shoreface nourishments placed at at Camperduin in 2002 (III), at Egmond aan Zee in 2004 (IV) and Bergen in 2005 (V).

a. Nourishments I. Egmond aan Zee 1999 and II. Bergen 2000

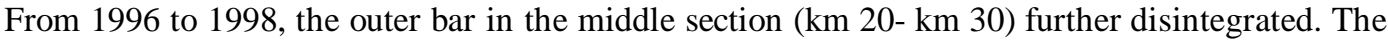
shoreface nourishments applied at Egmond aan Zee in 1999 (Figure 4c: I) and Bergen in 2000 (Figure 4c: II) first appear in the bathymetry of 2000 , as two relatively small berms, offshore of a fairly straight outer bar. Two years later (2002), the berms still remain isolated at their original location, but appear to have lowered considerably. Troughs developed on their shoreward side. By then, the outer bar has deformed into a zigzag shape, because the section aligned in between the berms migrated offshore, while the section aligned with the berms remained stable. The berms also appear to have partially connected with the outer bar. Four years later (2004), the berms have almost completely disappeared. By then, the outer bar appears to have gained sediment and resumed its autonomous offshore migration. 
b. Nourishment III. Camperduin 2002

In 2002, two bars are observed in the northern section: an outer bar, extending for more than $10 \mathrm{~km}$ to the north, and a new short inner bar near the shoreline. The outer bar was generated in 1990 , moved offshore and is in the first stage of decay by 2002. The inner bar was just generated at the shore. The shoreface nourishment at Camperduin in 2002 (Figure 5a: III), first observed in the bathymetry of 2004, was applied against the southern end of the existing outer bar. The nourishment is clearly higher and wider than the existing outer bar. By 2004, a deep trough has developed at its shoreward side. At the shoreline, the existing inner bar is forced shoreward and reconnects to the beach. After four years (2006), the berm has completely merged with the existing outer bar, and the resulting bar remains very stable. It even gains sediment, as opposed to the earlier Egmond and Bergen nourishments. Meanwhile, the inner bar does not migrate offshore. By 2008, the bar cycle resumes. The outer bar lowers slightly, and the inner bar starts moving offshore.

\section{c. Nourishments IV. Egmond aan Zee 2004 and V. Bergen 2005}

By 2004, the nourishments of 1999 and 2000 have almost fully disappeared from the middle section. The nourishments of 2004 (IV) and 2005 (V) are observed in the bathymetry of 2006, as two irregular berms, quite close to each other. By 2008, a very distinct trough has formed, and the bars have interconnected to a single bar. Meanwhile, the inner bar is forced back in the direction of the shoreline. The gap with the outer bar at Camperduin has reduced to about $2 \mathrm{~km}$. After four years (2010), the Bergen-Egmond bar remains clearly visible. The bar cycle does not appear to have resumed yet, since the inner bar remains near the shoreline. In the southern section, from 1996 to 2010 the bar cycle continues.

The lack of offshore deposition indicates that the sand eroded from the nourishments is more likely to be redistributed to the breaker zone, than to offshore.

\section{DISCUSSION AND CONCLUSIONS}

\section{Observed nourishment lifetime}

The results show that the lifetimes of the five shoreface nourishments applied at the NorthHolland coast differ considerably. The small and isolated Egmond 1999 and Bergen 2000 nourishments disappeared within two to three years. They interrupted the offshore bar migration at their position for about four years. The Camperduin 2002 nourishment fully merged with the preexisting outer bar and actually gained sediment, remaining in place and interrupting the autonomous bar behaviour for about six years. The large nourishments at Egmond (2004) and Bergen (2005) interconnected and remained much more stable than the earlier ones, interrupting the autonomous behaviour for over six years.

For a better understanding of these differences, the differentiating factors possibly influencing the lifetime of shoreface nourishments are considered. These factors include the external forcing (wave climate), sediment properties and the properties of the nourishment (water depth, size, and location). The latter may affect the lifetime indirectly through altering the local forcing mechanisms (e.g. wave breaking, wave-induced currents, etc).

\section{External forcing}

In view of the limited sediment transport capacity of the tide, most of the shoreface sediment dynamics will be wave-driven. Wijnberg (2002) observed little spatial variation in the offshore wave climate at the North-Holland coast. For an understanding of the temporal variation we analyzed the wave climate measured over the period 2000 to 2003, which was associated with rapid disintegration of the first two nourishments, and over the period 2003 to 2007 (associated with relatively stable berms). The result shows that the mean significant wave height of the first period $\left(\mathrm{H}_{\mathrm{s}}=0.92 \mathrm{~m}\right)$ was only slightly less than the second period $\left(\mathrm{H}_{\mathrm{s}}=1.06 \mathrm{~m}\right)$. In both periods, the prevailing wave directions were oblique most of the time $(\sim 70 \%)$, and slightly more often SW in the first period and NW in the second period. According to Walstra et al. (2012), the influence of the wave direction on the growth and decay of bars reduces with increasing water depth. Therefore, we expect the influence of differences in wave direction to be limited. 

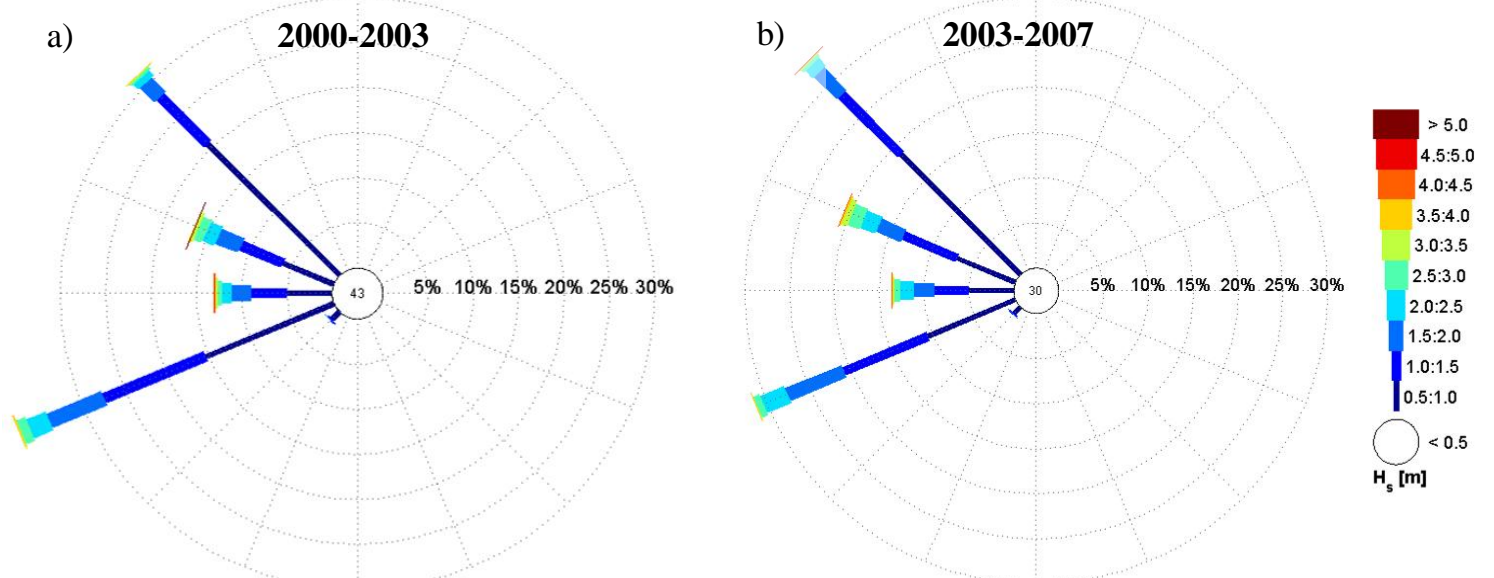

Figure 6: wave rose with measured wave conditions for the periods 2000-2003 (a) and 2004-2007 (b) (obtained from the MATROOS database).

\section{Sediment properties}

Based on our information, all the nourished sediment was non-cohesive sand with a grain-size distribution more or less comparable to that of the sediment on the outer banks. Therefore, we do not expect the sediment properties to be responsible for the observed lifetime differences.

\section{Water depth}

All nourishments were applied against the outer bar, at comparable offshore distance $(\sim 1 \mathrm{~km})$ and depth (up to NAP $-5 \mathrm{~m}$ ), in the zone where the outer bar autonomously decays. Hence, in this case, it does not explain the observed lifetime differences.

\section{Size}

The 1999 Bergen and 2000 Egmond nourishments with a volume of $\sim 1$ million $\mathrm{m} 3$ and a shoreparallel length of $\sim 2 \mathrm{~km}$ were about half the size of the later ones that had volumes of up to $\sim 2$ million $\mathrm{m} 3$ and lengths of 4 to $5 \mathrm{~km}$. This indicates that size, or actually length, possibly influences the nourishment lifetime, which is supported by the common idea that a larger volume will take more time to erode. Moreover, longer nourishments possibly have a more significant impact on the dynamics of the natural bars.

\section{Location}

The location of the first nourishments at Bergen and Egmond was more or less similar to the second round of nourishments there. Therefore, location alone is not discriminating. It appears that the stability of the second round of nourishments at Bergen and Egmond, and the Camperduin nourishment was influenced by their ability to connect to surrounding bars. In both cases, the bars that connected to a larger bar system were observed to have a significantly longer lifetime.

Although we gained a better understanding of the evolution and lifetime of five recently applied shoreface nourishments, there are a number of questions that remain unanswered. One major aspect concerns the benefit of the coastal profile. How much does the coastal profile benefit from a longer shoreface nourishment lifetime? Is the coastal profile actually restored? What are the contributions of the feeder and lee-effects? And lastly: where does the sand that is lost from the shoreface nourishments go to? A sediment budget analysis will help to better understand the sand-transport mechanisms and pathways. 


\section{REFERENCES}

Grunnet, N.M. and Ruessink, B.G., 2005. Morphodynamic response of nearshore bars to a shoreface nourishment. Coastal Engineering, 52, 119-137.

Hillen, R. and Roelse, P., 1995. Dynamic preservation of the coastline in the Netherlands. Journal of Coastal Conservation, 1, 17-28.

Ojeda, E., Ruessink, B.G. and Guillen, J., 2008. Morphodynamic response of a two-barred beach to a shoreface nourishment. Coastal Engineering, 55, 1185-1196.

Quartel, S., Ruessink, B.G. and Kroon, A., 2007. Daily to seasonal cross-shore behaviour of quasi-persistent intertidal beach morphology. Earth Surface Processes and Landforms, 32, 12931307.

Ruessink, B.G. and Kroon, A., 1994. The behaviour of a multiple bar system in the nearshore zone of Terschelling, the Netherlands: 1965-1993. Marine Geology, 121, 187-197.

Ruessink, B.G., Van der Grinten, R.M., Vonhögen-Peeters, L., Ramaekers, G. and Lodder, Q.J., 2012. Nearshore evolution at Noordwijk (NL) in response to nourishments, as inferred from Argus video imagery. In: W.M. Kranenburg, E.M. Horstman \& K.M. Wijnberg (eds.), Crossing Borders in Coastal Research, Jubilee Conference Proceedings, 20th NCK-days, Enschede, 13-16 March 2012, p. 179-183. DOI: 10.3990/2.194.

Shand, R.D., Bailey, D.G. and Shepherd, M.J., 1999. An inter-site comparison of net offshore bar migration characteristics and environmental conditions. Journal of Coastal Research, 15, 750-765.

Spanhoff, R., and Van de Graaff, J., 2007. Towards a better understanding and design of shoreface nourishments. Coastal Engineering 2006, Proceedings of the 30th International Conference, pp. 4141-4153.

Van Duin, M.J.P., Wiersma, N.R., Walstra, D.J.R., Van Rijn, L.C., and Stive, M.J.F., 2004. Nourishing the shoreface: observations and hindcasting of the Egmond case, The Netherlands. Coastal Engineering, 51, 813-837.

Van Koningsveld, M. and Mulder, J.P.M., 2004. Sustainable coastal policy developments in The Netherlands. A systematic approach revealed. Journal of Coastal Research, 20, 375-385.

Walstra, D.J.R., Reniers, A.J.H.M., Ranasinghe, R., Roelvink, J.A. and Ruessink, B.G., 2012. On bar growth and decay during interannual net offshore migration. Coastal Engineering, 60, 190-200.

Wijnberg, K.M., 1995. Morphologic behaviour of a barred coast over a period of decades. PhD thesis, Utrecht University, 245 pp.

Wijnberg, K.M., 2002. Environmental controls on decadal morphologic behaviour of the Holland coast. Marine Geology, 189, 227-247. 